\title{
Marin Sorescu - un autor complex
}

\author{
Drd. ANDONIE (ARDEAN) Raluca \\ Universitatea „Dunărea de Jos” din Galați
}

\begin{abstract}
Marin Sorescu has been defined as a complete author, proposing to his audience an ever-improved variety of the creative talent. As a poet, prose writer, playwright, essayist, literary, theatre and film critic, as well as a journalist, Sorescu has also remarked in the field of fine arts, having several exhibitions organized both within the country and abroad.

The author has a remarkable sense of using the non-obeying the conventional tactics, this is perhaps one of the central features of his writing and customization of the universal themes of literature, approaching them in a reader-friendly language. The same special talent is also visible within over 400 graphic works and paintings belonging to the great creative artist, emblematic for the Romanian literary context.

The plot and the playfulness of the approaches, these fundamental elements in one's development, the manner of approaching the terms of reality, and the practice of appropriating all representations, are the structures that seem to bond in such a harmonious structure, the Sorescian spirit.
\end{abstract}

Keywords: entertaining, playful, creative spirit, complex

Nu poți vorbi despre Marin Sorescu fără a evidenția fantastica descriere pe care i-a făcut-o George Călinescu în Contemporanul, în rubrica sa „Cronica optimistului": "Fundamental, Marin Sorescu are o capacitate excepțională de a surprinde fantasticul lucrurilor umile și latura imensă a temelor comune. Este entuziast și beat de univers, copilăros, sensibil și plin de gânduri până la marginea spaimei de ineditul existenței, romantic în accepția largă a cuvântului."

Vorbea oare de omul Marin Sorescu sau de autorul Marin Sorescu? Suntem înclinați să credem că vorbea de ambele ipostaze. Marin Sorescu s-a identificat până la dizolvare în opera sa.

După cum afirma Mihaela Andreescu în al său "Instantaneu critic” „Universul sorescian posedă o realitate concret-cerebrală, și o foame devoratoare de spațiu. El pare apt să se muleze pe întreaga suprafață a existentului, într-un efort deloc programatic, firesc ca respirația. Orice peisaj, împrumutat din real poate fi zămislit și renegat prin magia laică a gândirii sale paradoxale. Ceea ce conferă însă unicitate 
parcelelor disperse este tiparul inconfundabil al gândirii, spiritul sorescian, indiferent de decor și de substanță lingvistică."271

Și, nu în ultimul rând, s-a afirmat că "universul literaturii lui Marin Sorescu este nelimitat sub aspect fizic, fără a avea totuși înfățișarea unui bazar, ci rămânând organic și coerent, fiindcă este expresia nu a unei lumi, ci a unui fel de a privi lumea."

Incitați de aceste afirmații este ușor apoi a căuta și a descoperi opera lui Sorescu, care nu este un autor facil, dar este un scriitor complet și complex , care a știut, ca nimeni altul, să schimbe registrele, să se joace savant, în spațiul niciodată închis al prozei, să descopere lumi narative încă neexplorate.

Emina Căpălnășan, în cartea $O$ modernitate problematică: proza lui Marin Sorescu, reface, de pe coordonate ambițios strunite, traseul unei literaturi prea puțin ori parțial sondate, ajunse, până în prezent, cu vădite goluri ori pete de receptare.

Intrat pe nedrept într-un parțial con de umbră, de-abia acum ar putea începe lupta pentru recuperarea imaginii acestui autor emblematic în peisajul literaturii de la noi. Investigat cu instrumente diferite, înscris în paradigme paradoxale de receptare, Sorescu s-a lăsat anevoie recuperat de critica literară.

Experiența de cititor mă determină să afirmă ca nu reușești să scrii o părere constructivă despre cărțile unui autor dacă nu l-ai citit cu sufletul la gură, de la un capăt la altul, dacă nu îți este atât de aproape de suflet, în sensul în care te întorci mereu și mereu la el, ca la un colac de salvare. Opera lui Marin Sorescu deține magia de a te determina să te întorci mereu și mereu la ea pentru a descoperi alte sensuri, alte valențe.

Privind din altă perspectivă, câtă lume mai reține că Sorescu a fost un autor uriaș, nominalizat la Novel, deținător al Premiului Herder? În era sofisticatelor tehnologii cine își mai aduce aminte că Sorescu a fost și un mare dramaturg și traducător și eseist și critic literar pe lângă poezia sa unică? Prea puțini. Poate de aceea un prim pas spre normalitate este acela de a-l înfățișa pe Sorescu ca un autor complet și complex, care a avut darul de a șterge granițele dintre genurile literare.

Apărătoare înfocată a ideii de frumusețe în limbă, Emina Căpâlnășan „Proza lui Marin Sorescu - despre plăcerea jocului și despre ludic la nivel textual și intratextual" - găsește, în proza lui Marin Sorescu, multiple forme literare de salvare a lexicului românesc, a figurilor de limbaj, de renunțare la structurile care-i periclitează la tot pasul, spiritul. Avem astfel evidențiate perspectiva jocului afirmat în cuvinte

${ }^{271}$ Mihaela Andreescu, Marin Sorescu. Instantaneu critic, Editura Albatros, 1983, p. 20

272 Mircea Iorgulescu, Scriitori tineri contemporani, Editura Eminescu, 1978, p. 143 
neaoșe, ironia și subtilitatea dozării frazei, mecanismul diferit de fiecare dată de apropiere versatilă de cititor". ${ }^{273}$

Din microportretul creionat, pe ton sobru și echilibrat, de George Sorescu, în Prefața volumului tipărit de Ada Stuparu la finele anului 2017 a operei lui Marin Sorescu publicate postum, se punctează: „Poet, prozator, dramaturg, eseist și critic literar, grafician și pictor, apreciat de istoricii și criticii literari din țară și din afară, membru al câtorva academii, Marin Sorescu nu poate fi uitat azi (s.n.). I-am intuit geniul încă din perioada studiilor gimnaziale, liceale și universitare, respectându-i cu strictețe textele publicate în toate edițiile, antume și postume."274

George Sorescu scoate în prim-plan că Marin Sorescu era „stăpânit permanent de un daimon plăsmuitor tutelat de imaginație", apoi speculează, cu oarecare precauție: „Într-un fel, perenitatea operei lui trimite la versurile lui Horațiu din celebra Odă XXX: Nu voi muri întreg; din mine o parte, partea cea mai mare, va înfrânge Moartea și, prin slava ce-mi vor înălța urmașii, eu în orice veac la fel de tânăr voi crește fără încetare". 275

De-a lungul timpului, datorită complexității și originalității sale, Marin Sorescu a suscitat atât interesul criticilor literari cât și pe acela al teoreticienilor literari. În acest sens avem afirmația Mariei-Ana Tupan, istoric și teoretician literar: "Este interesant de observat că prozele satirice ale lui Marin Sorescu publicate în anii 1963 şi 1964 vizează nu atât realităţi ale timpului cât limbaje ale lor, forme de discurs, variantele lor textuale; relaţia dintre aceste proze şi lume rămâne tot timpul una de gradul doi, mediată de realitatea formalizată a limbajului". ${ }^{276}$

Aceeași autoare face trimitere la originalitatea lui Sorescu în comparație cu restul colegilor de breaslă, în oferirea conotaţiilor din poeziile sale:

„Moartea ceasului, titlul celui de al doilea volum de versuri originale, trimite la o emblemă favorită a moderniştilor, semnificând ieşirea dintr-un timp omogen, ruptură față de istoria anterioară, revoluție a valorilor. Pentru postmoderni, imaginea se incarcă de conotaţiile ieşirii din timp, repetiţiei sterile, sfârşitului istoriei şi umanismului. Pentru Marin Sorescu, timpul înseamnă direcție, înnoire, creație de valori." 277

\footnotetext{
273 Analele Universității Dunărea de Jos Galați: Fascicle XXIV, Lexic Comun / Lexic Specializat, 2013, Vol. 9, pp. 240-254.

${ }^{274} \mathrm{http}: / /$ www.observatorul.com/articles_main.asp?action=articleviewdetail\&ID=17905

$275 \mathrm{http}: / /$ www.opiniatr.ro/marin-sorescu-portret-stroboscopic/

${ }^{276} \mathrm{https} / / /$ www.agerpres.ro/flux-documentare/2016/02/19/documentar-opera-scriitoruluimarin-sorescu-08-00-05

277 Ibidem.
} 
Deși a fost considerată de marea majoritate a scriitorilor un gen minor, parodia, a fost luată foarte în serios de către Sorescu - să nu uităm că debutul său editorial din 1964 s-a produs cu volumul de parodii "Singur printre poeți". Tributar originalității sale, Sorescu a făcut o parodiere critică, anticalofilă împotriva tendinței de a da expresiei literare o atenție deosebită sau excesivă - și convențională, râzând atât de clasici cât și de debutanți. Umorul său fin avea o pișcătură amicală, pe care nu puteai să te superi, scoțând lucrurile cunoscute din convențiile lirice protocolare și academiste, drept pentru care a prins foarte bine la public, care l-a "gustat"din plin.

A fost decretat de G. Călinescu "tot ce poate fi mai nou în poezie si chiar în dramă".

Dar, chiar dacă „Poezia este o artă care doare. Doare atât cât doare arta. Toată arta la un loc nu ustură însă aşa de tare ca poezia. De ce? Pentru că ea este oscilograful omenirii. Cuvântul - mai mult decât o statuie, o pânză sau o clădire - se plachează direct pe geamătul, pe suspinul lumii, se îmbib̆̆, e stâlcit, rănit, sfârtecat... Versul e în chin, o sodomă de ispăşire şi purificare. Şi un mijloc de supraviețuire, o supapă... Cine nu ştie să folosească laserul vagului, nu e poet. Operație pe ochi cu laserul vagului - aceasta e poezia" ${ }^{278}$, după cum spunea Sorescu într-un documentar realizat pentru AGERPRES, o altă latură reprezentativă a sa este teatrul.

Piesa "Iona", publicată în 1968 în „Luceafărul” și premiată de către Uniunea Scriitorilor și Academia Română, apare în repertoriul multor teatre din lume fiind considerată o adevărată capodoperă. „Scriitor multilateral și inventiv, cuceritor printr-un sentimentalism discret, prin umor și prin grație stilistică"279, așa îl descrie Alex Ștefănescu într-un articol despre Marin Sorescu din Evenimentul Zilei.

Ca eseist, Sorescu s-a exprimat în vol. Teoria sferelor de influenţă (1969), Insomnii (1971), Starea de destin (1976), și culegerea de cronici literare Ușor cu pianul pe scări (1985). „Căuta să evite locurile comune. Incă din reportajele din tinerețe, publicate în revista Viaţa Studențească, vorbele din limbajul de lemn le punea mereu în ghilimele, ca o ironie. Asta făcea deliciul publicului", spunea profesorul Marin Beşteliu, care i-a fost un apropiat în timpul vieții, în încercarea sa de a-l contura pe Sorescu ca publicistul care a refuzat încă de la început temele curente.

\footnotetext{
278 https://www.agerpres.ro/flux-documentare/2016/02/19/documentar-operascriitorului-marin-sorescu-08-00-05

${ }^{279} \mathrm{http}$ ://evz.ro/ultima-mea-intalnire-cu-marin-sorescu-istoriile-lui-alex-stefanescu.html
} 
Faptul că, încet-încet, Marin Sorescu devine un model de identitate românească și că va ocupa locul pe care-l merită în galeria scriitorilor români, poate fi exemplificat prin povestioara lui Bogdan Crețu, semnatarul unui articol din numarul 4 din aprilie 2016 al revistei Contemporanul: „Povestea care urmează are pedagogia ei, de care mi-am dat seama mult mai târziu. Luasem cu mine cărți pentru a obține un autograf (era primul autograf al unui scriitor la care speram; mai aveam acasă un caiet." 280 În contrapunct cu așteptările adolescentului de la acea vreme avem afirmația făcută de Sorescu într-unul din numeroasele sale interviuri: „Eu nu sunt, la urma urmei, poet, dramaturg si eseist, ci ma consider scriitor, scrisul este profesia mea, si un scriitor trebuie sa tinda, macar, a fi cat mai complet."

Concluzia nu poate fi decât una singură - poet, dramaturg, eseist, prozator, critic literar de teatru și de film, ziarist, Marin Sorescu s-a impus ca un scriitor total, ocupând un spațiu foarte important atât calitativ, cât și cantitativ în literatura română, prin scrierile sale, fiind cunoscut și apreciat atât în țară, cât și în străinătate.

\section{BIBLIOGRAFIE}

Antofi, Simona, General Dictionary of Romanian Literature - Obverse and Reverse Critical Reception, în Oana Cenac (coord., edit.), International Conference of Common Vocabulary/Specialized Vocabulary: Manifestations of Creativity of Human Language, 6-7 iunie 2014, publicate în volumul MANIFESTARI ALE CREATIVITATII LIMBAJULUI UMAN, 2014, p. 13-19, ISBN:978-606-17-0623-5, Accession Number WOS:000378446400001

Andreescu Mihaela, Marin Sorescu. Instantaneu critic, Editura Albatros, 1983, p. 20

Cenac, Oana, (2014). Aspects of Popular Stylistic Language in the Work of Ion Creang $\breve{a}$ in Proceedings of the International Conference of Common Vocabulary/Specialized Vocabulary: Manifestations of Creativity of Human Language, 6-7 of June, 2014, p. 178 - 186, WOS: 000378446400018, citat în Nicoleta Hristu Hurmuzache, IDENTITATEA MALADIVĂ ÎN ROMANUL LUI MAX BLECHER, în volumul Spații culturale deschise. Latinitate și romanitate, Casa cărții de știință, Cluj-Napoca, 2016, ISBN 978-606-17-1081-2, WOS: 000378446400018

\footnotetext{
280 Vezi: $\quad$ http://www.contemporanul.ro/modele/bogdan-cretu-ce-am-invatat-de-lamarin-sorescu.html
} 
Ifrim, Nicoleta, Education and Interculturality in Approaching Post-totalitarian Identity Discourse: Interactive Views on Re-reading the Romanian Cultural Identity, Procedia-Social and Behavioral Journal (ISSN: 1877-0428) (ISSN: 1877-0509), vol. 93 / 2013, pp.18-22 - DOI: 10.1016/j.sbspro.2013.09.145 ELSEVIER (WOS:000342763100003, articol vizibil la adresa http://www.sciencedirect.com/science/article/pii/S1877042813032485,

Iorgulescu, Mircea, Scriitori tineri contemporani, Editura Eminescu, 1978, p. 143

Tupan Maria - Ana, Marin Sorescu și deconstrictivismul, Editura Scrisul Românesc, Craiova, 1995,.

https://www.agerpres.ro/flux-documentare/2016/02/19/documentar-opera-

scriitorului-marin-sorescu-08-00-05

http://evz.ro/ultima-mea-intalnire-cu-marin-sorescu-istoriile-lui-alex-

stefanescu.html

http://www.contemporanul.ro/modele/bogdan-cretu-ce-am-invatat-de-la-marinsorescu.html

http://www.observatorul.com/articles main.asp?action=articleviewdetail\&ID=1 7905

http://www.opiniatr.ro/marin-sorescu-portret-stroboscopic/ 